\title{
Effectiveness of Semi-fowler's Position on Hemodynamic Function among Patients with Traumatic Head Injury
}

\author{
Amal Said Taha ${ }^{1}$, Eman Sobhy Omran ${ }^{2}$ and Eman Adel Mahmoud Elweghi ${ }^{3}$
}

(1)Assistant Professor of Medical Surgical Nursing, Faculty of Nursing, Benha University (2) Lecturer of Medical-Surgical Nursing- Faculty of Nursing-Benha University (3) Nursing Educator at Albagour Secondary Technical Nursing School

\begin{abstract}
Head injury remains one of the most common causes of death worldwide. Approximately 10 to $50 \%$ of patients with head injury developed disability at some points of their illness, and represent one of the most common brain casualty encountered by neurosurgeons. Aim of the study: The study was aimed to determine the effectiveness of semi-fowler's position on the hemodynamic function among patients with traumatic head injury. Research design: A quasi-experimental research design was utilized in this study. Setting: The study was conducted at Emergency Care Unit at Benha University Hospital. Subjects: A convenient sample included 70 patients who were admitted at the above mentioned setting. Tools: Two tools were used: patient's assessment data and hemodynamic parameters assessment. Results: Demonstrated that less than half of the studied patients aged between $38-<48$ years old, $(87.1 \%)$ of them were males, (55.7\%) had traffic accident. As well, there were highly statistically significant relations between the semi-fowler's position and the studied patient's hemodynamic state and $\mathrm{ABG}$, indifferent assessment phases, there were highly statistically significant relations between the studied patients' age, gender, smoking habits and the APACHE score, there were highly statistically significant relations between the studied patients in semi-fowler's position and the Acute Physiology And Chronic Health Evaluation score in pre- position, after 15 and 30 minutes of the semi-fowler's position. Also, there were positive correlations between the studied patient's APACHE score and their Glasgow coma scale Conclusion: There were highly statistically significant relations between the semi-fowler's position and the studied patient's hemodynamic state and ABG results in different assessment phases of the study. Recommendations: Replication of the study using a larger probability sample from various geographical areas to attain more generalizable results. A study should be carried out on the aspects of knowledge, attitude, and skill towards therapeutic positions.
\end{abstract}

Key words: Hemodynamic function, Patients, Semi-fowler's position \& Traumatic head injury

\section{Introduction}

Traumatic Head injury (THI) is an important cause of preventable mortality and disability across the lifespan. By 2030, brain injuries due to traffic accidents and falls are expected to rise to the $7^{\text {th }}$ and $17^{\text {th }}$ major cause of death, respectively. THI ranges from mild to extremely severe injury. Recovery levels are similarly variable depending on the severity of the initial injury, from good outcome and resumption of premorbid lifestyles to profound disability affecting physical, cognitive and/or behavioral function. Although THI is a critical public health problem worldwide, the actual 
incidence is difficult to establish (Pozzato et al., 2020).

Traumatic head injury occur as a result of any trauma to the head such as car accidents, sports injuries, falls, self-injurious behaviors, violence, risky behavior, and other related acts. Whether the head injury is closed (no open wound) or open (perforation of the skull), such trauma has a wide range of impact which can be short or long-term in its duration of effects. Traumatic head injury results not only in problems with the brain but also THI can affect impacted individuals physically, cognitively, emotionally, and behaviorally (Harr et al., 2020).

The symptoms may include inability to remember the cause of the injury immediately before or up to 24 hours after being occurred; confusion and disorientation; difficulty remembering new information; headache; dizziness; blurry vision; nausea and vomiting; ringing in the ears; trouble speaking coherently; and changes in emotions or sleep patterns. The symptoms often appear at the time of the injury or soon after, but sometimes may not develop for days or weeks. Mild THI symptoms are usually temporary and clear up within hours, days or weeks; however, on occasion, they can last months or longer (Centers for Disease Control and Prevention (CDC), 2019).

Therapeutic positioning of the head of bed elevation has been proposed as a simple and effective way of preventing secondary brain injury in traumatic brain injury patients. Therapeutic head positioning has beneficial effects on brain physiology in severe THI. In neurosurgical critical care units, the head of bed is elevated to reduce ICP and maintain sufficient CPP. A head of bed elevation of 30 degrees is also a routine nursing practice in neurosurgical intensive care units for patients with traumatic brain injury. The practice is important because it increases the cerebral perfusion pressure by reducing the Mean Arterial Blood Pressure (MAP) and maintains the Cerebral Blood Flow (CBF) (EL Mokadem \& EL-Sayed, 2020).

\section{Significance of the study:}

According to the Center for Disease Control and Prevention (CDC), over 1.7 million individuals sustain traumatic head injury annually, resulting in over 53,000 deaths and 500,000 patients developing permanent neurologic damage. In Egypt, the overall incidence of traumatic head injury was 2,124 patients in 2016. Sixty-two percent of the patients had a mild head injury, $17.5 \%$ had moderate head injury, and $20.3 \%$ had severe head injury (EL Mokadem \& ELSayed, 2020).

Critical care nurses must be aware of the patient's hemodynamic state and the effect of various nursing interventions on these parameters. Knowledge about the patient's hemodynamics, and which interventions affect these parameters, enables the critical care nurse to plan care that is best suited to that individual patient. Also, it enables critical care nurses to modify any interventions that might compromise CPP to reduce the danger to the patient's cerebrovascular status (Nyholm et al., 2020).

\section{Aim of the study}

The aim of the present study was to determine the effectiveness of semi-fowler 


\section{Amal Said Taha, Eman Sobhy Omran and Eman Adel Mahmoud Elweghi}

position on the hemodynamic function among patients with traumatic head injury through:

- Assessing the hemodynamic function of patients with traumatic head injury.

- Examining the effectiveness of semi-fowler position on improving the hemodynamic function among patients with traumatic head injury.

\section{Research hypothesis:}

Patients with traumatic head injury who received semi-fowler's position will exhibit improvement in hemodynamic function than those who did not receive.

\section{Subjects and Methods}

\section{Aim of the study:}

This study aimed to determine the effectiveness of semi-fowler's position on hemodynamic function among patients with traumatic head injury through:

-Assess hemodynamic function of patients with traumatic head injury.

-Examine the effectiveness of semi-fowler's position on improving hemodynamic function among patients with traumatic head injury.

\section{Research Hypothesis:}

Patients with traumatic head injury who receives semi -fowler's position will exhibit improvement in hemodynamic function than those who did not receive

The subject and methods of the current study were designed under the following main four designs:

I. Technical Design

II. Operational Design

III. Administrative Design

IV. Statistical Design

\section{Technical Design}

It Included research design, study settings, subject and tools of data collection.

\section{Research Design}

A Quasi-experimental design was used to examine the effect of semi-fowler's position 30 degree on hemodynamic function among patients with traumatic head injury.

\section{Setting}

This study was conducted at Emergency Care Unit in Benha University Hospital from the beginning of November 2019 till the end of April 2020.

\section{Subjects}

A convenient sample include 70 patients were admitted at the above mentioned setting up to six months. Emergency care unit has a big room that contain 10 beds .It receives patients from all over the Kalubeia Governorate.

Subjects were included in the study according to the following criteria:

\section{Inclusion Criteria}

1- Patients of both genders (male \& female)

2-Patients with closed head injury with Glasgow Coma Scale (GCS) less than 8 score.

\section{Exclusion Criteria}

1-Spinal cord injury

2-Patients with fever

3-Ischemic patients

\section{Tools for data collection:}

The following two tools were constructed, tested and piloted by the investigator to collect data through:

Tool I- Patients' assessment data: 
It was developed by the researcher after reviewing the related national and international literature. It was written in a simple Arabic language to suit the understanding level of the study subject.

It entails two parts as the following:

\section{Part 1:}

Socio-demographic data includes patient's age, gender, marital status, education level, residence, and occupation and smoking habits.

\section{Part 2:}

Patient medical history: Includes associated disease as (causes and complication and medical history related head injury).

\section{Tool II. Hemodynamic parameters assessment:}

Include acute physiology and chronic Health Evaluation II scale (APACHE II scale): it was developed by Knanus et al, (1985) it was one of several ICU scoring systems that was designed to measure the severity of disease for adult patients admitted to Emergency Care units. It was applied within 24 hours of admission of patient to an emergency care unit; an integer score from (0 to 71) was computed based on several measurements; higher scores correspond to more severe disease and a higher risk of death.

\section{1- Hemodynamic parameters assessment includes:}

- Pulse Rate (PR) Respiratory Rate (RR)

- Systolic Blood Pressure (SBP) Diastolic Blood Pressure (DBP)

- Mean Arterial pressure (MAP) Central Venous Pressure (CVP)

- Partial Pressure of Arterial Oxygen (PaO2)
- Partial Pressure of Arterial Carbon Dioxide (PaCo2)

- Saturation of Arterial Oxygen (Sao2).

2- Acute Physiology and Chronic Health Evaluation II Scale (APCHE II SCALE).

APACHE II was designed to measure the severity of disease for adult patients admitted to Emergency Care Unit. It is applied within the first 24hours of patient admission to the Emergency Care Unit; an integer score from 0 to 71 is computed based on several measurements such as patient's age and 12 routine physiological measurements (pao2 (depending on fio2), Body temperature, Mean Arterial Pressure (MAP), Arterial PH, Heart Rate, Respiratory Rate, Serum Sodium, Serum Potassium, Creatinine, Hematocrit, White Blood Cell Count (WBC), Glasgow Coma Scale).

- Interpretation of APACHE II Scores (predicted mortality rate)

- APACHE II score (0 -4) indicates the severity of patient condition with Mortality risk $4 \%$.

- APACHE II score (5-9) indicates the severity of patient condition with Mortality risk $\sim 8 \%$.

- APACHE II score (10-14) indicates the severity of patient condition with Mortality risk $\sim 15 \%$.

- APACHE II score (15 -19) indicates the severity of patient condition with Mortality risk $\sim 25 \%$.

- APACHE II score (20 -24) indicates the severity of patient condition with Mortality risk $\sim 40 \%$. 
- APACHE II score (25-29) indicates the severity of patient condition with Mortality risk $55 \%$.

- APACHE II score (30- 34) indicates the severity of patient condition with Mortality risk $\sim 75 \%$.

- APACHE II score > 34 indicates the severity of patient condition with Mortality risk $\sim 85 \%$.

\section{3- Glasgow Coma Scale (GCS)}

The Glasgow Coma Scale (GCS) is a neurological scale was published in 1974 by Graham Teasdale and Bryan J. GCS was used to assess a person's level of consciousness after a head injury, A patient is assessed against the criteria of scale, and the resulting points give a patient score .The maximal total score for a fully awake and alert person is 15. A minimal score of 3 is consistent with complete lack of responsiveness. A total score of 3 to 8 suggests severe impairment, 9 to 12 suggests moderate impairment, and 13 to 15 suggest mild impairment the scale is now used by emergency medical services, nurses, and physicians as being applicable to all acute medical and trauma patients.

\section{- Elements of the scale}

1. Eye response $(\mathrm{E})$

2. Verbal response (V)

3. Motor response (M)

- Glasgow Coma Scale score:

Mild

Moderate (9-12)

Severe

Tool Validity and Reliability:

\section{Content Validity:}

Test face and content validity of the suggested tool by a jury of five experts in Medical Surgical Nursing department in Faculty of Nursing Benha University and two doctors from Faculty of Medicine, Benha University to determine whether the included items are clear and suitable to achieve the aim of the current study. Their opinions elicited regarding the format, layout, consistency, accuracy and relevancy of the tools.

- Reliability analysis by measuring of internal consistency of the tool through Cronbach's Alpha test.

\begin{tabular}{|l|c|}
\hline \multicolumn{1}{|c|}{ Tool } & Cronbach's Alpha \\
\hline $\begin{array}{l}\text { Patients' assessment } \\
\text { data }\end{array}$ & .798 \\
\hline $\begin{array}{l}\text { Hemodynamic } \\
\text { parameters assessment }\end{array}$ & .824 \\
\hline $\begin{array}{l}\text { Acute Physiology and } \\
\text { Chronic Health } \\
\text { Evaluation II Scale }\end{array}$ & 0.849 \\
\hline Glasgow Coma Scale & 0.886 \\
\hline
\end{tabular}

\section{Operational Designed}

It included operational design for this study consisted of four phases, namely preparatory phase, ethical considerations, pilot study, and fieldwork.

\section{Preparatory Phase}

This phase included extensive reviewing literature and studies related to present study using national and international resource in order to develop the appropriate tools of data collection. Developing tools to assess effectiveness of semi fowler's position on hemodynamic function among patients with traumatic head injury and translation into Arabic language. 
-An official permission will be obtained by the researcher from dean of Benha Faculty of Nursing and hospital administrative personnel to conduct the study after explanation the purpose of the study.

\section{Ethical Considerations}

The research approval was obtained from the Faculty Ethical Committee before starting the study.

\section{The ethical research considerations include} the following:

- A written /oral consent was obtained from relative of the subject who was meeting the study inclusion criteria to participate in the study.

At the initial interview relative was informed about the purpose, procedure and benefits of the study and the researcher was explain to the relatives that participation in the study is voluntary and the patient can withdraw from the study at any time without penalty.

- The relatives of the subjects were informed that they are allowed to choose to participate or not in the study and they have the right to withdrawal from the study at any time.

- Confidentiality and anonymity of patient was assured through coding all data and put all paper in a secured closed cabinet.

\section{Pilot Study:}

Carried out on 7 patients those represent $10 \%$ of patients at Emergency Care Unit at Benha University Hospital affiliated to Benha University. In order to test the applicability of the constructed tools and the clarity of the included questions related to patients' hemodynamic parameters. The pilot has also served to estimate the time needed for each subject to fill in the questions. According to the results of the pilot, some corrections and omissions of items were performed so the pilot patients were not included in the main study sample.

\section{Fieldwork:}

\section{- Assessment phase}

-Researcher collected patients' demographic data from patients' records by using tool (I) \& tool (II) which includes age, gender, duration of illness, medical history and medication. And measure physiological data (respiratory rate, pulse and blood pressure).

\section{Planning phase:}

-Researcher assessed conscious level at the initial admission time to Emergency Care Unit without sedation by using Glasgow coma scale (GCS) for every subject to detect the severity of traumatic head injury within the first $48 \mathrm{~h}$ of hospital admission.

\section{Implementation phase:}

- The researcher visited the study setting 4 days / weekly (Saturday, Sunday, Monday and Tuesday) at morning shift and afternoon shift to collect data.

-Researcher collected the demographic data and medical history from patients' record by using Tool I (Patient assessment data).

-Researcher assessed the severity level by using APACHE Scale for studied group patient to detect the severity of traumatic head injury \& hemodynamic parameters within the first 24hours of hospital admission. 


\section{Amal Said Taha, Eman Sobhy Omran and Eman Adel Mahmoud Elweghi}

-Each patient was placed in semi fowler's position $30^{\circ}$. The choice of 30 degree elevation for this study was based on the traditional recommendations prescribed for the head injured patients as well as anatomical and scientific data. All patients had a15 minute rest before position so that any previous nursing activities will not affect the studied variables.

-Every studied patient positioned in the $30^{\circ}$ semi-fowler position for 15 minutes until stabilization of patient hemodynamic. No nursing activities are done during the 15 minutes after positioning in order not to affect patient's hemodynamic parameters.

-The researcher assess patient's hemodynamic function by using hemodynamic parameters assessment after 15 minute, then the patient positioned in the $30^{\circ}$ semi-fowler position for 30 minutes then the researcher assess patient's hemodynamic function again after 30 minutes .

\section{Evaluation phase:}

-Evaluation of studied patients was done for two times during the study, the first one on pre intervention and second one post intervention.

-Comparison was done between pre \& post intervention to examine effectiveness of semi fowler's position on hemodynamic function among patients with traumatic head injury.

\section{Administrative Designed:}

An official permission to conduct the study obtained from the director of Benha University Hospital affiliated to Benha University. The researcher met the hospital director and explained the purpose and the methods of the data collection.

\section{Statistical Analysis}

Data collected from the studied sample was revised, coded and entered using Personal Computer (PC). Computerized data entry and Statistical analysis were fulfilled using the Statistical Package for Social Sciences (SPSS) version 22. Data were presented using descriptive statistics in the form of frequencies, percentages. Chi-square test $\left(\mathrm{X}^{2}\right)$ was used for comparisons between qualitative variables.

\section{Significance of the results:}

- Highly significant at p-value $<0.01$.

Statisticall

$\mathrm{y}$ significant was considered at p-value $<0.05$.

- Non-

significant at $\mathrm{p}$-value $>0.05$.

\section{Results}

Table(1):"The sociodemographic data of present study among studied patients" included age, gender, marital status, educational level, residence, occupation and smoking habits .Regarding age $(37.1 \%)$ of the studied patients 'age were $(38-<48)$ years old with a mean age and standard deviation of (37.1 \pm 6.94 SD) and range of (18-65) years old. Regarding gender, the majority $(87.1 \%)$ of studied patients were male. Concerning marital status, three quarters (75.7\%) of the studied patients were married .Regarding the educational level $(41.4 \%)$ of the studied patients had secondary education. Concerning occupation, (70\%) of the studied patients were workers. Concerning smoking habits, $(64.3 \%)$ of the studied patients were smokers while $(48.9 \%)$ of the smoker patients were cigarettes smokers. As for residence, more than half of studied patients $(55.7 \%)$ were living in urban areas.

Table (2) demonstrates distribution of medical history -related data of the studied patients. The table reveals that the majority of 
studied patients had not any chronic illness such as Diabetes mellitus, Hypertension, Cardiac disease, Renal disease, Liver disease, Pulmonary disease, Immunity disease $(97.1 \%, 98.6 \%$ ,97.1\% , 100\%, $98.6 \quad \% \quad 98.6 \quad \% \quad 100 \%$ Respectively).

Table (3) demonstrates mortality risk of studied patients' pre - position intervention. The table reveals that $(34.3 \%)$ of studied patients had APACHE II score (25 -29), (24.3\%) of them had APACHE II score (30 -34) and $(17.1 \%)$ of them had APACHE II score (10 14). Also, the table shows that the mean APACHE score of studied patients was (23.78 \pm 5.4$)$.

Table (4) shows that there were highly statistically significant relations between the semi-fowler's position and the studied patients' hemodynamic State in pre- position, after 15 min and 30 minutes post the semi-fowler's Position $(P<0.001)$.

Table (5) shows that there were highly statistically significant relations between the semi-fowler's position and the studied patients' arterial blood gases results in pre- position, after
15 and 30 minutes of the semi-fowler's position $(P<0.001)$.

Table (6) shows that (22.8\%) of studied patients who had APACHE score from (25-29) were in the age of 38 to less than 48 years old. The table also shows that there were highly statistically significant relations between the studied patients' age and the APACHE score.

Table (7) shows that $(30.0 \%)$ of studied patients who had APACHE score from (25-29) were males. The table also shows that there were highly statistically significant relations between the studied patients' gender and the APACHE score.

Table (8) reveals that there were highly statistically significant relations between the studied patients in semi-fowler's position and the APACHE score in pre- position and after 15 and 30 minutes of the semi-fowler's position $(P<0.001)$.

Table (9) indicates that there were highly statistically significant positive correlations between the studied patients' APACHE score and their Glasgow Coma Scale $(P<0.001)$. 


\section{Amal Said Taha, Eman Sobhy Omran and Eman Adel Mahmoud Elweghi}

Table (1): Distribution of studied patients according to their sociodemographic characteristics $(\mathrm{N}=70)$.

\begin{tabular}{|c|c|c|}
\hline \multicolumn{2}{|l|}{ Sociodemographic data } & $\%$ \\
\hline \multicolumn{3}{|l|}{ Age ( in years) } \\
\hline $18-<28$ & 14 & 20 \\
\hline $28-<38$ & 20 & 28.6 \\
\hline $38-<48$ & 26 & 37.1 \\
\hline $48+$ & 10 & 14.3 \\
\hline \multicolumn{3}{|l|}{ Range $=$ Min - Max $\quad(18-65)$} \\
\hline \multicolumn{3}{|l|}{ 37.1 $\pm 6.94 \mathrm{SD}$} \\
\hline \multicolumn{3}{|l|}{ Gender } \\
\hline Male & 61 & 87.1 \\
\hline Female & 9 & 12.9 \\
\hline \multicolumn{3}{|l|}{ Marital status } \\
\hline Single & 9 & 12.9 \\
\hline Married & 53 & 75.7 \\
\hline Divorced & 5 & 7.1 \\
\hline Widow & 3 & 4.3 \\
\hline \multicolumn{3}{|l|}{ Educational level } \\
\hline Illiterate & 9 & 12.9 \\
\hline Primary education & 13 & 18.6 \\
\hline Secondary education & 29 & 41.4 \\
\hline Bachelor & 15 & 21.4 \\
\hline Post graduate & 4 & 5.7 \\
\hline \multicolumn{3}{|l|}{ Residence } \\
\hline Rural & 31 & 44.3 \\
\hline Urban & 39 & 55.7 \\
\hline \multicolumn{3}{|l|}{ Occupation } \\
\hline Work & 49 & 70 \\
\hline Not work & 21 & 30 \\
\hline \multicolumn{3}{|l|}{ Smoking habits } \\
\hline Smoking & 45 & 64.3 \\
\hline No smoking & 25 & 35.7 \\
\hline \multicolumn{3}{|l|}{ If smoking, type $(\mathrm{N}=54)$} \\
\hline Cigarettes & 22 & 48.9 \\
\hline Shisha & 13 & 28.9 \\
\hline Both cigarettes and shisha & 10 & 22.2 \\
\hline
\end{tabular}


Table (2): Frequency and percentage distribution of medical history -related data of the studied patients $(\mathrm{N}=70)$.

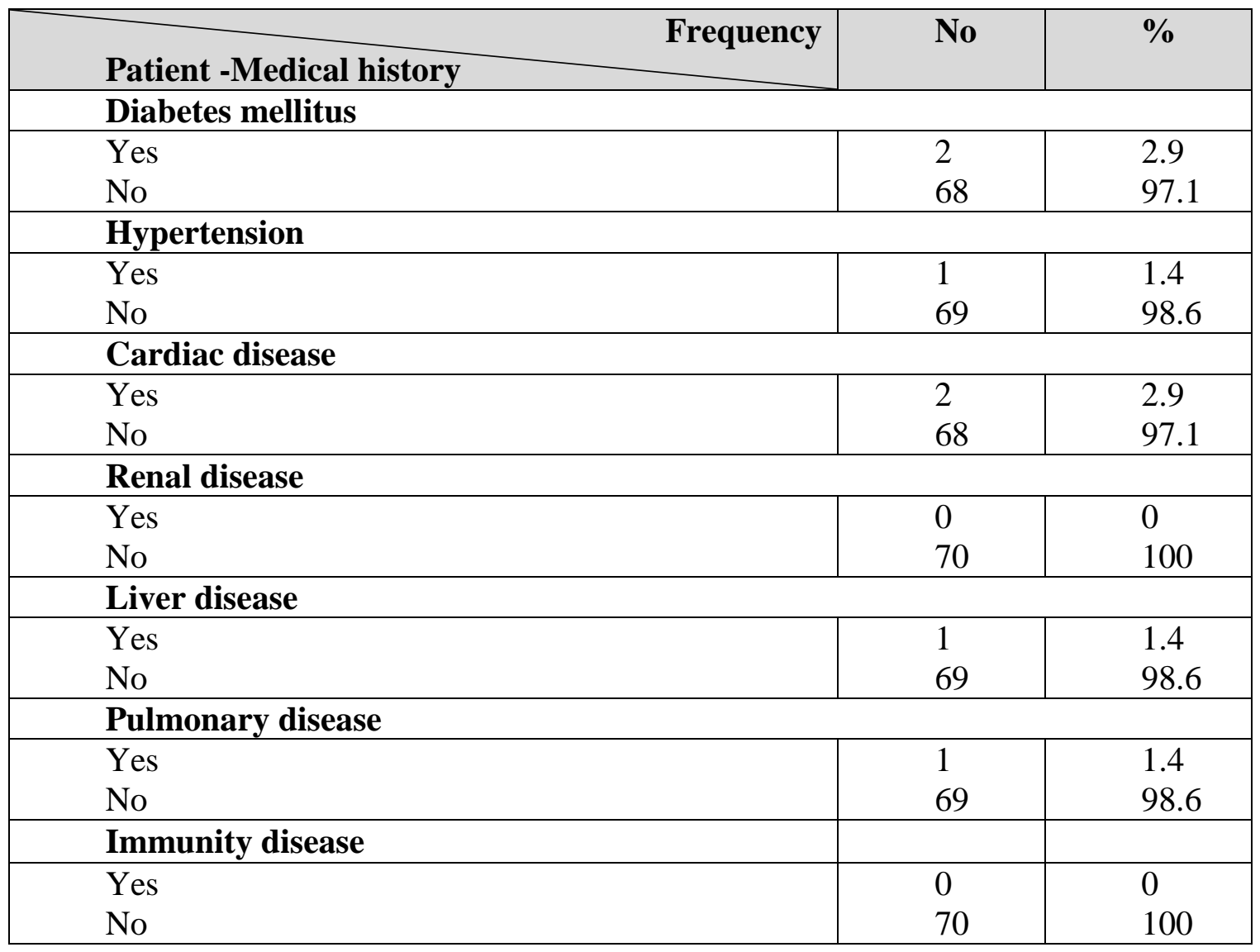

Table (3): Frequency and percentage distribution of studied patients regarding Acute Physiology and Chronic Health Evaluation II score pre -position intervention $(\mathrm{N}=70)$

\begin{tabular}{|l|l|l|l|}
\hline *APACHE score Frequency & Mortality risk & No & \% \\
\hline APACHE II score ( 0 -4 ) & $4 \%$ & 0 & 0 \\
\hline APACHE II score ( 5 -9 ) & $8 \%$ & 0 & 0 \\
\hline APACHE II score ( 10 -14 ) & $15 \%$ & 12 & 17.1 \\
\hline APACHE II score ( 15 -19) & $25 \%$ & 9 & 12.9 \\
\hline APACHE II score ( 20 -24 ) & $40 \%$ & 8 & 11.4 \\
\hline APACHE II score ( 25 -29) & $55 \%$ & 24 & 34.3 \\
\hline APACHE II score (30 -34 ) & $75 \%$ & 17 & 24.3 \\
\hline APACHE II score >34 & $85 \%$ & 0 & 0 \\
\hline \multicolumn{2}{|c|}{ Mean \pm S.D $\mathbf{2 3 . 7 8} \pm \mathbf{5 . 4}$} \\
\hline Maximum $\mathbf{1 0}$ \\
\hline Range (10 - 34)
\end{tabular}

*APACHE II Score: Acute Physiology And Chronic Health evaluation II Score .

\section{JNSBU}




\section{Amal Said Taha, Eman Sobhy Omran and Eman Adel Mahmoud Elweghi}

Table (4): Relation between the semi-fowler's position and the studied patients' hemodynamic state $(\mathrm{N}=70)$.

\begin{tabular}{|c|c|c|c|c|c|}
\hline \multirow{3}{*}{ Hemodynamic state } & \multicolumn{3}{|c|}{ The semi-fowler's position } & \multirow{2}{*}{\multicolumn{2}{|c|}{ Significance test }} \\
\hline & $\begin{array}{c}\text { Pre- } \\
\text { nosition }\end{array}$ & $\begin{array}{l}\text { After } 15 \\
\text { min from }\end{array}$ & After $30 \mathrm{~min}$ & & \\
\hline & $\pm \mathrm{SD} \overline{\mathrm{X}}$ & $\pm \mathrm{SD} \overline{\mathrm{X}}$ & $\pm \mathrm{SD} \overline{\mathrm{X}}$ & t-test & p-value \\
\hline Pulse rate & $97.6 \pm 6.4$ & $91.33 \pm 5.8$ & $88.41 \pm 6.1$ & 13.75 & $<0.001 * *$ \\
\hline Respiratory rate & $19.8 \pm 2.7$ & $16.4 \pm 1.99$ & $15.7 \pm 2.0$ & 12.80 & $<0.001 * *$ \\
\hline Systolic pressure & $133.4 \pm 16.2$ & $128.6 \pm 13.5$ & $127.8 \pm 12.6$ & 12.45 & $<0.001 * *$ \\
\hline Diastolic pressure & $82.11 \pm 9.3$ & $79.10 \pm 6.8$ & $78.3 \pm 5.7$ & 13.99 & $<0.001 * *$ \\
\hline Mean arterial pressure & $86.72 \pm 6.1$ & $82.40 \pm 5.4$ & $80.01 \pm 6.9$ & 14.77 & $<0.001 * *$ \\
\hline Central venous pressure & $3.58 \pm 1.9$ & $3.42 \pm 1.67$ & $3.29 \pm 1.45$ & 16.08 & $<0.001 * *$ \\
\hline
\end{tabular}

$* *=$ Highly statistically significant at $\mathrm{p}$ value $<0.01$

Table (5): Relation between the semi-fowler's position and the studied patients' Arterial Blood Gases ( $\mathrm{N}=70)$.

\begin{tabular}{|c|c|c|c|c|c|}
\hline \multirow{3}{*}{ * ABG items } & \multicolumn{3}{|c|}{ The semi-fowler's position } & \multirow{2}{*}{\multicolumn{2}{|c|}{ Significance test }} \\
\hline & $\begin{array}{c}\text { Pre- } \\
\text { nosition }\end{array}$ & $\begin{array}{l}\text { After } 15 \\
\text { min from }\end{array}$ & After $30 \mathrm{~min}$ & & \\
\hline & $\pm \mathrm{SD} \overline{\mathrm{X}}$ & $\pm \mathrm{SD} \overline{\mathrm{X}}$ & $\pm \mathrm{SD} \overline{\mathrm{X}}$ & t-test & p-value \\
\hline $\begin{array}{l}\text { Partial Pressure of Arterial } \\
\text { Oxygen }(\mathrm{PaO2})\end{array}$ & $81.5 \pm 4.6$ & $85.3 \pm 3.6$ & $87.2 \pm 3.5$ & 14.88 & $<0.001 * *$ \\
\hline $\begin{array}{l}\text { Partial Pressure of Arterial } \\
\text { Carbon Dioxide (PaCo2) }\end{array}$ & $42.6 \pm 3.2$ & $38.7 \pm 2.8$ & $37.01 \pm 2.8$ & 12.90 & $<0.001 * *$ \\
\hline $\begin{array}{l}\text { Saturation of Arterial } \\
\text { Oxygen (Sao2) }\end{array}$ & $92.30 \pm 5.9$ & $94.6 \pm 4.1$ & $94.9 \pm 3.6$ & 15.80 & $<0.001 * *$ \\
\hline
\end{tabular}

*ABG Arterial Blood Gases

$* *=$ Highly statistically significant at $\mathrm{p}$ value $<0.01$ 
Table (6): Relation between the studied patient's APACHE score and their socio- demographic characteristics related to age, $(\mathrm{N}=70)$.

\begin{tabular}{|c|c|c|c|c|c|c|c|c|c|c|}
\hline \multirow{3}{*}{ APACHE score } & \multicolumn{8}{|c|}{ The patients' age } & \multicolumn{2}{|c|}{ Significance test } \\
\hline & \multicolumn{2}{|c|}{$18-<28$} & \multicolumn{2}{|c|}{$28-<38$} & \multicolumn{2}{|c|}{$38-<48$} & \multicolumn{2}{|c|}{$48+$} & \multirow{2}{*}{$\mathbf{X}^{2}$} & \multirow{2}{*}{ P-value } \\
\hline & No & $\%$ & No & $\%$ & No & $\%$ & No & $\%$ & & \\
\hline $\begin{array}{l}\text { APACHE II score } \\
(10-14)\end{array}$ & 4 & 5.7 & 6 & 8.6 & 1 & 1.4 & 1 & 1.4 & 18.84 & $<0.001 * *$ \\
\hline $\begin{array}{l}\text { APACHE II score } \\
(15-19)\end{array}$ & 2 & 2.9 & 4 & 5.7 & 2 & 2.9 & 1 & 1.4 & 26.46 & $<0.001 * *$ \\
\hline $\begin{array}{l}\text { APACHE II score } \\
(20-24)\end{array}$ & 2 & 2.9 & 3 & 4.3 & 1 & 1.4 & 2 & 2.9 & 19.13 & $<0.001 * *$ \\
\hline $\begin{array}{l}\text { APACHE II score } \\
(25-29)\end{array}$ & 3 & 4.3 & 3 & 4.3 & 16 & 22.8 & 2 & 2.9 & 17.90 & $<0.001 *$ \\
\hline $\begin{array}{l}\text { APACHE II score } \\
(30-34)\end{array}$ & 3 & 4.3 & 4 & 5.7 & 6 & 8.6 & 4 & 5.7 & 18.55 & $<0.001 * *$ \\
\hline
\end{tabular}

APACHE II Score : Acute Physiology And Chronic Health evaluation II Score

$*=$ Statistically significant at $\mathrm{P}$ value $\leq 0.05$

$* *=$ Highly statistically significant at $\mathrm{p}$ value $<0.01$

Table (7): Relation between the studied patient's APACHE score and their socio-demographic characteristics related to gender, $(\mathrm{N}=70)$.

\begin{tabular}{|c|c|c|c|c|c|c|}
\hline \multirow{3}{*}{ APACHE score } & \multicolumn{4}{|c|}{ The patients' gender } & \multicolumn{2}{|c|}{ Significance test } \\
\hline & \multicolumn{2}{|c|}{ Male } & \multicolumn{2}{|c|}{ Female } & \multirow{2}{*}{$\mathbf{X}^{2}$} & \multirow[b]{2}{*}{ P-value } \\
\hline & No. & $\%$ & No. & $\%$ & & \\
\hline APACHE II score (10 -14) & 10 & 14.3 & 2 & 2.9 & 14.99 & $<0.001 * *$ \\
\hline APACHE II score (15 -19) & 8 & 11.4 & 1 & 1.4 & 18.55 & $<0.001 * *$ \\
\hline APACHE II score (20 -24) & 6 & 8.6 & 2 & 2.9 & 13.59 & $<0.001 * *$ \\
\hline APACHE II score (25 -29) & 21 & 30.0 & 3 & 4.3 & 17.66 & $0.001 *$ \\
\hline APACHE II score ( 30 -34 ) & 16 & 22.8 & 1 & 1.4 & 16.22 & $<0.001 * *$ \\
\hline
\end{tabular}

APACHE II Score : Acute Physiology And Chronic Health evaluation II Score

$*=$ Statistically significant at $\mathrm{P}$ value $\leq 0.05$

$* *=$ Highly statistically significant at $\mathrm{p}$ value $<0.01$ 


\section{Amal Said Taha, Eman Sobhy Omran and Eman Adel Mahmoud Elweghi}

Table (8): Relation between the studied patients in semi-fowler's position and theAcute Physiology And Chronic Health Evaluation score, $(\mathrm{N}=70)$.

\begin{tabular}{|c|c|c|c|c|c|}
\hline \multirow{3}{*}{ *APACHE score } & \multicolumn{3}{|c|}{$\bar{T}^{\text {The semi-fowler's position } 30^{\circ}}$} & \multirow{2}{*}{\multicolumn{2}{|c|}{ Significance test }} \\
\hline & Pre- & After 15 & After $30 \mathrm{~min}$ & & \\
\hline & $\overline{\mathrm{X}} \pm \mathrm{SD}$ & $\overline{\mathrm{X}} \pm \mathrm{SD}$ & $\overline{\mathrm{X}} \pm \mathrm{SD}$ & T-test & P-value \\
\hline APACHE II score ( 5 -9 ) & $0.00 \pm 0.00$ & $0.257 \pm 1.51$ & $0.514 \pm 2.10$ & 15.71 & $<0.001 * *$ \\
\hline APACHE II score ( 10 -14 ) & $2.01 \pm 4.49$ & $2.35 \pm 4.79$ & $2.94 \pm 5.29$ & 13.30 & $<0.001 * *$ \\
\hline APACHE II score ( 15 -19) & $2.05 \pm 5.40$ & $2.04 \pm 5.36$ & $3.80 \pm 7.13$ & 14.29 & $<0.001 * *$ \\
\hline APACHE II score ( 20 -24 ) & $2.47 \pm 6.94$ & $3.44 \pm 8.05$ & $4.34 \pm 8.77$ & 12.59 & $<0.001 * *$ \\
\hline APACHE II score ( $25-29$ ) & $9.32 \pm 13.03$ & $7.75 \pm 12.37$ & $4.97 \pm 10.50$ & 16.33 & $<0.001 * *$ \\
\hline APACHE II score ( 30 -34) & $7.71 \pm 13.73$ & $5.82 \pm 12.30$ & $3.15 \pm 9.55$ & 14.22 & $<0.001 * *$ \\
\hline
\end{tabular}

*AP *APACHE: Acute Physiology And Chronic Health Evaluation.

$* *=$ Highly statistically significant at $\mathrm{p}$ value $<0.01$

Table (9): Correlation between the studied patients APACHI score and the Glasgow coma scale, $(\mathrm{N}=70)$.

\begin{tabular}{|c|c|c|c|c|c|c|}
\hline \multirow{3}{*}{ Variables } & \multicolumn{6}{|c|}{ APACHI score } \\
\hline & \multicolumn{2}{|c|}{ Pre- position } & \multicolumn{2}{|c|}{ After 15 min } & \multicolumn{2}{|c|}{ After 30 min } \\
\hline & $\mathbf{r}$ & P-value & $\mathbf{r}$ & P-value & $\mathbf{r}$ & P-value \\
\hline \multirow[t]{3}{*}{ Glasgow coma scale } & 0.485 & $0.009 * *$ & & & & \\
\hline & & & 0.629 & $0.001 * *$ & & \\
\hline & & & & & 0.780 & $0.001 * *$ \\
\hline
\end{tabular}

*APACHE: Acute Physiology and Chronic Health Evaluation. $\quad * *=$ Highly statistically significant at $\mathrm{p}$ value $<0.0$

\section{Discussion}

Traumatic head injury (THI) is one of the prevalent causes of global death and disability. Lately, head injury (HI) cases have increased in both developed and developing nations. Therefore, one of the great values is to evaluate the clinical and pathological features of head injury. In addition, the patients' positioning has a profound effect on hemodynamic stability of head injured patients (Refaat et al., 2019).

This study aimed to: determine the effectiveness of semi-fowler position on the hemodynamic function among patients with traumatic head injury through the following: assessing the hemodynamic function of patients with traumatic head injury and examining the effectiveness of semi-fowler 
position on improving the hemodynamic function among patients with traumatic head injury.

To fulfill the aim of this study, the discussion of the findings is presented in the following sections.

\section{Section I: Socio-demographic data of the studied patients.}

Regarding age; the current study revealed that more than one third of studied patients were within the age group of 38 to less than 48 years old with a mean age and standard deviation of $37.1 \pm 6.94$ and range of (18 - 65) years old, while the majority of them were males. From the researchers' point of view, this may be because this age is the most commonly affected.

These results disagreed with Halldorsson et al., (2017), who conducted study about Urban-Rural Differences in Pediatric Traumatic Head Injuries: A Prospective Nationwide Study, and stated that an increased risk for traumatic head injury is in the age group from (0-4 year) and the majority for females.

These results also disagreed with a study done in the emergency department in England about Head Injury: Triage, Assessment, Investigation and Early Management of Head Injury in Children, Young People and Adults by NICE (2017), who found that $50 \%$ of the traumatic head injury cases were children aged less than 15 years, both sexes are affected while the majority were for females.
As regards marital status and educational level; the current study showed that slightly more than three quarter of studied patients were married, and more than one third of them had secondary education. From the researchers' point of view, these results may be because this is the most commonly time for marriage and the most observed level of education among the majority of people, hence this period is the most critical in men's life in which they tried to work hard in one or more job to cover their family's needs which may increase the risk of the exposure to motor car accidents due to the excessive tiredness.

These findings were in accordance with El Hendawy et al., (2020), whose study was about Surgical Management of Open Traumatic Head Injury, and stated that the majority of the studied patients were married and more than half of them had secondary education.

Concerning the residence and occupation; the present study findings denoted that more than half of the studied patients were living in urban areas and less than three quarters of them were working. From the researchers' point of view, these results may be because the chance of work in the urban areas is more than those found in the rural community.

These results were agreed with Elbaih et al., (2018), who conducted study about Patterns of Brain Injuries Associated with Maxillofacial Fractures and its Fate in Emergency Egyptian Poly-trauma Patients, and found that the majority of the studied patients were living in urban areas and more 


\section{Amal Said Taha, Eman Sobhy Omran and Eman Adel Mahmoud Elweghi}

than two thirds of them were governmental employers.

As for smoking habits; less than one third of the studied patients were Cigarettes smokers. From the researchers' point of view, this result may be because many people think that smoking helps them to concentrate in work specially when working in more than one place while others consider smoking as a kind of entertainment. This result was in agreement with Ostberg \& Tenovuo, (2019), who developed study about Smoking and Outcome of Traumatic Brain Injury, and stated that most of the studied patients were cigarettes smokers and added that smoking is associated with the outcome from traumatic head injury.

\section{Section II: The patients' medical history.}

Regarding the medical history; the present study results revealed that the majority of the studied patients didn't have any chronic diseases such as diabetes mellitus, hypertension, cardiac diseases, renal diseases, liver diseases, pulmonary diseases, or immunity diseases. From the researchers' point of view this may be because all these diseases may require the presence of family history and the studied patients didn't have any history of disease. These results were agreed with the results of Hawley et al., (2017), who developed study about Traumatic Brain Injuries in Older Adults, and found that the majority of the studied patients didn't suffer from any chronic diseases.

Concerning the studied patients' Acute Physiology and Chronic Health Evaluation APACHE II score; the present study results revealed that more than one third of the studied patients had APACHE II score of (25
-29) pre-intervention and the mean APACHE II score of studied patients was (23.78 \pm 5.4$)$. These results were against the results of Nik et al., (2018), who developed study about The Efficacy of Glasgow Coma Scale (GCS) Score and Acute Physiology and Chronic Health Evaluation (APACHE) II for Predicting Hospital Mortality of ICU Patients with Acute Traumatic Brain Injury, and found that the overall, mean score of APACHE II scale for all the studied patients was

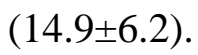

Regarding the relation between the semi-fowlers' position and the studied patients' hemodynamic state; the study results showed that there were highly statistically significant relations between the semi-fowlers' position and the studied patient's hemodynamic state in pre-position, and after $15 \mathrm{~min}$ and 30 minutes post the semi-fowler's position $(\mathrm{P}<0.001)$. These findings were accordance with Mehta \& Parmar, (2017), who performed study about the Effect of Positional Changes on Oxygenation in Patients with Head Injury in the Intensive Care Unit, and found that there were highly statistically significant relations between the mean values of vital parameters (arterial oxygen saturation, heart rate, respiratory rate, blood pressure) of the studied patients and the semi-fowlers' positions at 15 and 30 minutes.

As for the relation between the semifowlers' position and the studied patients' Arterial Blood Gases; the present study results showed that there were highly statistically significant relations between the semi-fowlers' position and the studied patients' $A B G$ results in pre-position, and after 15and 30 minutes of the semi-fowlers' position $(\mathrm{P}<0.001)$. These results were in 
accordance with Oddo \& Bösel (2014), who performed study about Monitoring of Brain and Systemic Oxygenation in Neuro-critical Care Patients, and found that the semifowlers' positioning of the neuro-critically ill patients has statistically significant relations with the patients' $(\mathrm{PaO} 2, \mathrm{PaCO} 2$, and $\mathrm{SaO} 2)$ results.

The same results disagreed with Thomas et al., (2013), who studied the Effect of Seated and Semi-recumbent Position on Gas Exchange, Respiratory Mechanics, and Hemodynamics of 34 Intensive Care Patients, and revealed that putting the patients in the semi-fowlers' position with the head of the bed elevated $45^{\circ}$ for 30 minutes showed no statistically significant difference in the respiratory rate and the arterial blood gases values $(\mathrm{PaO} 2, \mathrm{PaCO} 2$, and $\mathrm{SaO} 2)$.

\section{Regarding the relation between the studied} patient's APACHE II score and their age; the present study showed that there were highly statistically significant relation between the studied patients' age and the APACHE II score $(\mathrm{P}<0.001)$. From the researchers' point of view the health outcome of patients with traumatic head injury is usually affected by age as the younger patients usually recovers early to the absence of most of the chronic diseases. This finding was in accordance with Kandil et al., (2017), who studied Traumatic Brain Injury Predictive Value of Common Intensive Care Severity Scores, and found that there were highly statistically significant relation between the studied patients' age and their APACHE II score $(\mathrm{P}<0.005)$.

This result was also in accordance with Rahu et al., (2016), who developed study about Predicting Six-month Mortality of Patients with Traumatic Brain Injury: Usefulness of Common Intensive Care Severity Scores, and found that the age had a statistically significant impact on the outcome of the studied patients with traumatic head injury through measuring the APACHE II score $(\mathrm{P}<0.002)$.

The same result disagreed with Edipoglu et al., (2017), who studied the Association Between the APACHE-II Scores and Age Groups for Predicting Mortality in an Intensive Care Unit: A retrospective Study, and found that there was no statistically significant relation between the studied patients' age and the APACHE II score.

As for the relation between the studied patient's APACHE II score and their gender; the present study illustrated that there was highly statistically significant relation between the studied patients' gender and the APACHE II score $(\mathrm{P}<0.001)$. From the researchers' point of view usually the male patients recovered early than the female one due to the physical fitness they have. This finding was in the same line with Khoshfetrat et al., (2020), who developed study about The Ability of GCS, FOUR, and APACHE II in Predicting the Outcome of Patients with Traumatic Brain Injury: A Comparative Study, and found that there was highly statistically significant relation between the studied patients' gender and the APACHE II score as the male patients showed early recovery than the female patients.

Regarding the relation between the studied patients in semi-fowler's position and the APACHE II score; the present study showed that there were highly 


\section{Amal Said Taha, Eman Sobhy Omran and Eman Adel Mahmoud Elweghi}

statistically significant relations between the studied patient's in semi-fowler's position and the APACHE II score in pre- position, and after 15and 30 minutes of the semifowlers' position $(\mathrm{P}<0.001)$. This result was in the same line with $\boldsymbol{A b d}$ El-Moaty et al., (2017), who performed study about Effect of Semi Fowler's Positions on Oxygenation and Hemodynamic Status among Critically Ill Patients with Traumatic Brain Injury, and found that the APACHE II score of the studied patients is statistically significant affected by the semi-fowlers' position $(\mathrm{P}<0.005)$.

Concerning the studied patients' APACHIE II score and their Glasgow Coma Scale; finding of the present study demonstrated that there were highly statistically significant positive correlations between the studied patient's APATCHE II score and their Glasgow coma scale $(\mathrm{P}<0.001)$. This finding was in the same line with Nejmi et al., (2018), who conducted study about the Ability of Two Scoring Systems to Predict In-hospital Mortality of Patients with Moderate and Severe Traumatic Brain Injuries in a Moroccan intensive care unit, and reported that there were highly statistically significant positive correlations between the studied patient's APATCHE II score and their Glasgow coma scale $(\mathrm{P}<0.002)$.

This result was also in agreement with Brinkman et al., (2017), who studied Prediction of Long-term Mortality in ICU Patients: Model Validation and Assessing the Effect of Using In-hospital Versus Long-term Mortality on Benchmarking, and found that there were highly statistically significant positive correlation between the studied subject's APACHE II score and their Glasgow Coma Scale $(\mathrm{P}<0.005)$.

Furthermore, this result disagreed with Nik et al., (2018), who stated that there were no statistically significant positive correlation between the studied patients APACHE II score and their Glasgow Coma Scale, suggesting that APACHE II score is not necessarily a better mortality predictor in patients with head trauma.

\section{Conclusion:}

There were highly statistically significant relations between the semifowler's position and the studied patient's hemodynamic state and $A B G$ results in different assessment phases of the study.

\section{Recommendations:}

Replication of the study using a larger probability sample from various geographical areas to attain more generalizable results. A study should be carried out on the aspects of knowledge, attitude, and skill towards therapeutic positions.

\section{References}

Abd El-Moaty, A., EL-Mokadem, N., \& Abd-Elhy, A. (2017). Effect of Semi Fowler's Positions on Oxygenation and Hemodynamic Status among Critically Ill Patients with Traumatic Brain Injury. International Journal of Novel Research in Healthcare and Nursing; 4(2): PP.227-236.

Brinkman, S., Abu-Hanna, A., Jonge, E., \& Keizer, N. (2017). Prediction of long-term mortality in ICU patients: model validation and assessing the effect of using in-hospital versus long-term mortality on benchmarking. Intensive Care Med 2013; 39:1925-1931.

Centers for Disease Control and Prevention (CDC), (2019). Symptoms of Traumatic Brain Injury (TBI). Available at: 
https://www.cdc.gov/traumaticbraininjury/sym ptoms.html. Accessed on 26 August 2020

Edipoglu, I., Dogruel, B., Dizi, S., Tosun, M., \& Cakar, N. (2017). The association between the APACHE-II scores and age groups for predicting mortality in an intensive care unit: a retrospective study. Rom J Anesthesia Intensive Care; 26(1): PP.53-58.

Elbaih, AH., El-sayed, D., Abou-Zeid, A. (2018). Patterns of brain injuries associated with maxillofacial fractures and its fate in emergency Egyptian polytrauma patients. Chin J Traumatol; 21(5): PP.287-292.

El-Hendawy, M., Mohammed, M., \& Saad, A. (2020). Management of open traumatic head injury. The Egyptian Journal of Hospital Medicine; 78 (1): P. 42-4742.

Ellis, E., \& Han, S. (2017). Skull fractures. Available at: https://www.healthline.com/health/skullfracture\#outlook. Accessed on 30 August 2017.

EL-Mokadem, N., \& EL-Sayed, S. (2020). Effect of positioning during suctioning on cerebral perfusion pressure among patients with traumatic brain injury. American Journal of Nursing Research; 8(4): PP.435-441.

Halldorsson, J., Flekkoy, K., Gudmundsson, K., Arnkelsson, G., \& Arnarson, E. (2017). Urban-Rural Differences in Pediatric Traumatic Head Injuries: A Prospective Nationwide Study. Journal of Neuropsychiatric Disease and Treatment; 3(6): PP.935-941.

Harr, D., Brown, J., Luckhardt, B., \& Kivisalu, T. (2020). Traumatic brain injury
(TBI): A beginner's guide for education professionals. Annals of Psychiatry and Clinical Neuroscience; 1(1): P. 2.

Hawley, C., Sakr, M., Scapinello, S., Salvo, J., \& Wrenn, P. (2017). Traumatic brain injuries in older adults- 6 years of data for one UK trauma centre: retrospective analysis of prospectively collected data. Medical Journal; 34: PP.509-516.

Kandil, A., Kenawi, M., Samir, A., \& Hussein, K. (2017). Traumatic brain injury predictive value of common intensive care severity scores. Research and Opinion in Anesthesia and Intensive Care; 4(3): PP.124128.

Khoshfetrat, M., Yaghoubi, M., Hosseini, B., \& Farahmandrad, R. (2020). The ability of GCS, FOUR, and APACHE II in predicting the outcome of patients with traumatic brain injury: A comparative study. The Vietnams Journal of Medicine; 2(7): PP. 3614-3621.

Mehta, J., \& Parmar, L. (2017). The effect of positional changes on oxygenation in patients with head injury in the intensive care unit. Journal of Family Medicine and Primary Care; 6(4): PP.853-858.

Nejmi, H., Rebahi, H., Ejlaidi, A., Abouelhassan, T., \& Samkaoui, M. (2018). The ability of two scoring systems to predict in-hospital mortality of patients with moderate and severe traumatic brain injuries in a Moroccan intensive care unit. Indian Journal of Critical Care Medicine; 18(6): PP.369-375. NICE, (2014). Head Injury: Triage, Assessment, Investigation and Early Management of Head Injury in Children, Young People and Adults. NICE Clinical Guideline, United Kingdom. National 


\section{Amal Said Taha, Eman Sobhy Omran and Eman Adel Mahmoud Elweghi}

Institute for Health and Clinical Excellence: Guidance.

Nik, A., Andalibi, M., Ehsaei, M., Zarifian, A., Karimiani, E., \& Bahadoorkhan, G. (2018). The Efficacy of Glasgow Coma Scale (GCS) Score and Acute Physiology and Chronic Health Evaluation (APACHE) II for Predicting Hospital Mortality of ICU Patients with Acute Traumatic Brain Injury. Bull Emergency Trauma; 6(2): PP.141-145.

Oddo, M., \& Bösel, J. (2014). Participants in the International Multidisciplinary Consensus Conference on Multimodality Monitoring. Monitoring of brain and systemic oxygenation in neuro-critical care patients. Neurocrit Care; 21 Suppl 2:S103-20.

Ostberg, A., \& Tenovuo, O. (2019). Smoking and Outcome of Traumatic BrainInjury.Availableat:https://www.research gate.net/publication/259880691_Smoking_and _outcome_of_traumatic_brain_injury.

Accessed on 23 September 2020

Rahu, R., Skrifvars, M., Bendel, S., Selander, T., Kivisaari, R., Siironen, J., \& Reinikainen, M. (2016). Predicting six-month mortality of patients with traumatic brain injury: usefulness of common intensive care severity scores. Crit Care 2014; 18: PP.60-73.

Refaat, A., Haroun, M., Sharaf Eldin, A., Hussein, A., \& Abdelkader, A. (2019). Medicolegal aspects of traumatic head injuries in Benha university hospital prospective analytical study. Egypt Journal of Forensic Sci. Applied Toxicology; 19 (4): P. 119. 
تأثير الوضع نصف جالس علي وظيفة الدورة الدموية بين المرضى المصابين بإصابات في الرأس

$$
\text { إيمان عادل محمود - أمل سعيد طه - إيمان صبحي عمران }
$$

تعرف إصابات الرأس بأنها الأضرار التي تلحق بالدماغ بعد التعرض الي قوة خارجية والتي تتسبب في إحداث خلل وظيفي مؤقت أو دائم للاماغ ركما تعتبر إصابات الرأس سببا رئيسيا للوفاة بـاة

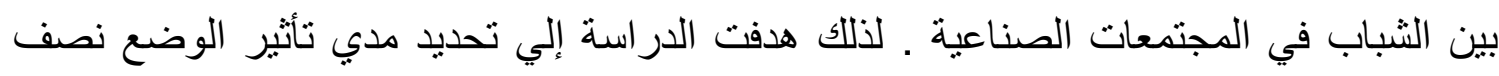
جالس علي وظيفة الدورة الدموية بين المرضى المصابين بإصابات في الرأس ـ وقد أجريت الدراسة في وحدة رعاية الطوارئ بمستشفي بنها الجامعي علي • من المرضي المصابين

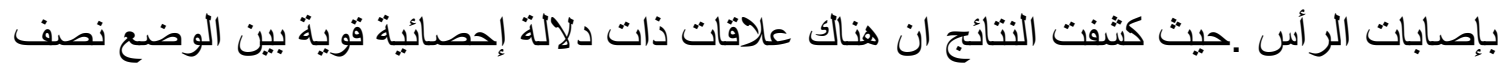
جالس وحالة الدورة الدموية للمرضي قبل ذللك الوضع وبعد مرور خمسة عشر دقيقة منه وكذلك بعد مرور ثلاثون دقيقة لنفس الوضع ركما وجدت علاقات ذات دلائل إجصائية قوية بين الوضع نصف جالس ونتيجة غاز ات الدم الخاصة بالمرضي قبل ذلك الوضع وبعد مرور خمسة عشر دقيقة منه وكذلك بعد مرور ثلاثون دقيقة لنفس الوضع. كما أوصت الدراسة إلي تكرار الدراسة

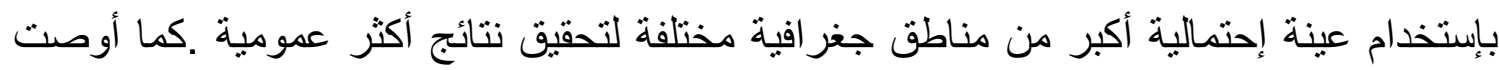
بتطبيق هذه الدراسة والتي تهدف الي تحسين معلومات ,إتجاهات ,ممارسات ممرضات الرعاية

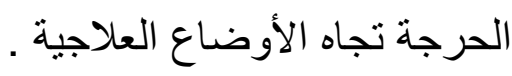

\section{JNSBU}

